\title{
Transient Receptor Potential A1 Is a Sensory Receptor for Multiple Products of Oxidative Stress
}

\author{
David A. Andersson, Clive Gentry, Sian Moss, and Stuart Bevan \\ Wolfson Centre for Age-Related Diseases, King's College London, London SE1 1UL, United Kingdom
}

Transient receptor potential A1 (TRPA1) is expressed in a subset of nociceptive sensory neurons where it acts as a sensor for environmental irritants, including acrolein, and some pungent plant ingredients such as allyl isothiocyanate and cinnamaldehyde. These exogenous compounds activate TRPA1 by covalent modification of cysteine residues. We have used electrophysiological methods and measurements of intracellular calcium concentration $\left(\left[\mathrm{Ca}^{2+}\right]_{\mathrm{i}}\right)$ to show that TRPA1 is activated by several classes of endogenous thiolreactive molecules. TRPA1 was activated by hydrogen peroxide $\left(\mathrm{H}_{2} \mathrm{O}_{2} ; \mathrm{EC}_{50}, 230 \mu \mathrm{M}\right)$, by endogenously occurring alkenyl aldehydes $\left(\mathrm{EC}_{50}\right.$ : 4-hydroxynonenal $19.9 \mu \mathrm{M}$, 4-oxo-nonenal $1.9 \mu \mathrm{M}$, 4-hydroxyhexenal $38.9 \mu \mathrm{M}$ ) and by the cyclopentenone prostaglandin, 15deoxy- $\Delta^{12,14}$-prostaglandin $\mathrm{J}_{2}\left(15 \mathrm{~d}-\mathrm{PGJ}_{2}, \mathrm{EC}_{50}: 5.6 \mu \mathrm{M}\right)$. The effect of $\mathrm{H}_{2} \mathrm{O}_{2}$ was reversed by treatment with dithiothreitol indicating that $\mathrm{H}_{2} \mathrm{O}_{2}$ acts by promoting the formation of disulfide bonds whereas the actions of the alkenyl aldehydes and $15 \mathrm{~d}-\mathrm{PG} \mathrm{J}_{2}$ were not reversed, suggesting that these agents form Michael adducts. $\mathrm{H}_{2} \mathrm{O}_{2}$ and the naturally occurring alkenyl aldehydes and $15 \mathrm{~d}-\mathrm{PG} \mathrm{J}_{2}$ acted on a subset of isolated rat and mouse sensory neurons [ $\sim 25 \%$ of rat dorsal root ganglion (DRG) and $\sim 50 \%$ of nodose ganglion neurons] to evoke a depolarizing inward current and an increase in $\left[\mathrm{Ca}^{2+}\right]_{\mathrm{i}}$ in TRPA1 expressing neurons. The abilities of $\mathrm{H}_{2} \mathrm{O}_{2}$, alkenyl aldehydes and $15 \mathrm{~d}-\mathrm{PG} \mathrm{J}_{2}$ to raise $\left[\mathrm{Ca}^{2+}\right]_{\mathrm{i}}$ in mouse DRG neurons were greatly reduced in neurons from trpa1 ${ }^{-1-}$ mice. Furthermore, intraplantar injection of either $\mathrm{H}_{2} \mathrm{O}_{2}$ or 15d-PGJ2 evoked a nocifensive/pain response in wild-type mice, but not in trpa1 ${ }^{-1-}$ mice. These data demonstrate that multiple agents produced during episodes of oxidative stress can activate TRPA1 expressed in sensory neurons.

Key words: TRPA1; DRG; hydrogen peroxide; 4-hydroxynonenal; $15 \mathrm{~d}-\mathrm{PGJ} \mathrm{J}_{2}$; oxidative stress

\section{Introduction}

The transient receptor potential A1 (TRPA1) channel is a nonselective cation channel expressed by a subset of primary afferent nociceptive neurons where it acts as a sensory receptor for some pungent chemicals found in plants, including allyl isothiocyanate (from mustard and wasabi), cinnamaldehyde (from cinnamon), and allicin (in garlic). TRPA1 can also be activated by some other agents including methylsalicylate, icilin, and the environmental irritant, acrolein (Bandell et al., 2004; Jordt et al., 2004; Bautista et al., 2005, 2006) and mediates some responses to proinflammatory mediators, such as bradykinin (Bandell et al., 2004; Jordt et al., 2004; Bautista et al., 2006).

Site directed mutagenesis studies have shown that allyl isothiocyanate (AITC), cinnamaldehyde and acrolein activate TRPA1 by covalently reacting with cysteine residues in the cytoplasmic $\mathrm{N}$ terminus of the channel (Hinman et al., 2006; Macpherson et al., 2007a). TRPA1 can therefore act as a sensor of reactive, electrophilic chemicals. It has been unclear if there are endogenous electrophilic activators of TRPA1. To address this question, we have investigated whether endogenous thiol reactive agents activate TRPA1. For these studies we have studied the

\footnotetext{
Received July 16, 2007; revised Jan. 18, 2008; accepted Jan. 20, 2008.

This work was supported by the Medical Research Council. We thank Dr. Terry Hart for discussion.

Correspondence should be addressed to David A. Andersson, Wolfson Centre for Age-Related Diseases, King's

College London, Guy's Campus, London SE1 1UL, UK. E-mail: david.andersson@kcl.ac.uk.

DOI:10.1523/JNEUROSCI.5369-07.2008

Copyright $\odot 2008$ Society for Neuroscience $\quad 0270-6474 / 08 / 282485-10 \$ 15.00 / 0$
}

responsiveness of heterologously expressed TRPA1 channels and sensory neurons from wild-type rats and mice and TRPA1-null mice as well as the pain behaviors of TRPA1-null mice. Our studies have focused on several thiol reactive chemicals that are produced during oxidative stress and inflammation.

Oxidative stress occurs during many pathophysiological conditions including inflammation and reperfusion after ischemia and results in the production of a range of highly reactive chemicals including hydrogen peroxide $\left(\mathrm{H}_{2} \mathrm{O}_{2}\right)$, lipid peroxidation products such as 4-hydroxynonenal (4-HNE), and 15-deoxy$\Delta^{12,14}$-prostaglandin $\mathrm{J}_{2}\left(15 \mathrm{~d}-\mathrm{PGJ}_{2}\right)$ (Hyslop et al., 1995; Sprong et al., 1997; Chen et al., 1999; Gao et al., 2003; Uchida, 2003). $\mathrm{H}_{2} \mathrm{O}_{2}$, which stimulates a subset of capsaicin-sensitive sensory nerves innervating the heart, lungs and gastrointestinal tract (Stahl et al., 1993; Ustinova and Schultz, 1994b; Soukhova et al., 1999; Ruan et al., 2006), is known to oxidize cysteine residues in proteins to form either cysteine sulfenic acids or disulfides (Poole et al., 2004). 4-HNE and related lipids, 4-oxo-2-nonenal (4ONE) and 4-hydroxyhexenal (4-HHE), are highly reactive products of lipid peroxidation that contain an electrophilic $\alpha, \beta$ unsaturated carbonyl moiety similar to that found in the TRPA1 agonist, cinnamaldehyde. These lipid peroxidation products can form adducts with lysine, histidine, and cysteine residues (Uchida, 2003). Finally cyclopentenone prostaglandins (cyPGs), produced from arachidonic acid via cyclooxygenase and prostaglandin $\mathrm{D}_{2}\left(\mathrm{PGD}_{2}\right)$ synthase or nonenzymatically during oxidative stress (Chen et al., 1999; Gao et al., 2003), also contain elec- 
trophilic $\alpha, \beta$-unsaturated carbonyl moieties and are known to be thiol reactive compounds (Levonen et al., 2004).

\section{Materials and Methods}

Cell culture. Untransfected Chinese hamster ovary $(\mathrm{CHO})$ cells and $\mathrm{CHO}$ cells expressing mouse TRPA1, mouse TRPM8, rat TRPV4, or human TRPV1 were grown in MEM- $\alpha$ medium supplemented with penicillin $(100 \mathrm{U} / \mathrm{ml})$, streptomycin $(100 \mu \mathrm{g} / \mathrm{ml})$, L-glutamine $(2 \mathrm{~mm})$, and FCS (10\%).

Dorsal root ganglion (DRG) and nodose ganglion neurons were prepared from adult $(\sim 200 \mathrm{~g})$ male or female Wistar rats using methods described previously (Bevan and Winter, 1995). TRPA1-null mice and wild-type littermates were bred from heterozygotic mice kindly provided by Drs. Kelvin Kwan (Harvard Medical School, Boston, MA) and David Corey (Harvard Medical School, Boston, MA) (Kwan et al., 2006). DRG neurons from TRPA1-null and TRPV1-null mice and their respective wild-type littermates were prepared using the protocol used for rat neurons. The chemosensitivities of DRG and nodose neurons were investigated $18-48 \mathrm{~h}$ after plating the cells on laminin/poly-D-lysine-coated coverslips.

Imaging of intracellular calcium levels. CHO cells and DRG neurons were loaded with $2 \mu \mathrm{M}$ Fura-2 AM (Invitrogen, Carlsbad, CA) in the presence of $1 \mathrm{~mm}$ probenecid for $\sim 1 \mathrm{~h}$. The dye loading and the subsequent experiments were performed in a physiological saline solution containing (in mM) $140 \mathrm{NaCl}, 5 \mathrm{KCl}, 10$ glucose, $10 \mathrm{HEPES}, 2 \mathrm{CaCl}_{2}$, and $1 \mathrm{MgCl}_{2}$, buffered to $\mathrm{pH} 7.4(\mathrm{NaOH})$. Compounds were applied to cells by local continuous microperfusion of solution through a fine tube placed very close to the cells being studied. Experiments were conducted at $30^{\circ} \mathrm{C}$. Images of a group of cells were captured every $2 \mathrm{~s}$ using 340 and $380 \mathrm{~nm}$ excitation wavelengths with emission measured at $520 \mathrm{~nm}$ with a microscope based imaging system (PTI, Birmingham, NJ). Analyses of emission intensity ratios at $340 \mathrm{~nm} / 380 \mathrm{~nm}$ excitation ( $\mathrm{R}$; in individual cells) were performed using the ImageMaster suite of software.

Electrophysiology. CHO cells expressing TRPA1 were studied under voltage-clamp conditions using an Axopatch 200B amplifier and pClamp 10.0 software (Molecular Devices, Sunnyvale, CA). Whole-cell recordings from $\mathrm{CHO}$ cells were performed at a holding potential of $-60 \mathrm{mV}$, unless stated otherwise. Drugs and solutions were applied by local superfusion using a rapid solution changer (Bio-Logic, Claix, France). Borosilicate glass pipettes ( $2-5 \mathrm{M} \Omega, 75-80 \%$ series resistance compensation) were filled with (in mM) $140 \mathrm{KCl}, 1 \mathrm{CaCl}_{2}, 2 \mathrm{MgATP}, 10 \mathrm{EGTA}$, and 10 HEPES buffered to $\mathrm{pH}$ 7.4 (KOH). The external solution was as described above for imaging of intracellular $\mathrm{Ca}^{2+}$ concentrations. In experiments with $\mathrm{Ca}^{2+}$-free external solutions, 1 mM EGTA was included and $\mathrm{CaCl}_{2}$ was omitted. Cell-attached single-channel recordings were performed using the $\mathrm{Ca}^{2+}$-free external solution both in the pipette and for superfusion. Inside-out patches were superfused on the cytoplasmic side with a solution containing (in mM) $110 \mathrm{KCl}, 10 \mathrm{Na}_{5} \mathrm{P}_{3} \mathrm{O}_{10}, 1 \mathrm{CaCl}_{2}, 1$ $\mathrm{MgCl}_{2}, 10$ HEPES, and 10 EGTA, pH 7.4 (KOH). $\mathrm{Na}_{5} \mathrm{P}_{3} \mathrm{O}_{10}$ was included to maintain channel activity in isolated patches (Kim and Cavanaugh, 2007). For inside-out patch recordings, pipettes were filled with the external solution described above for $\mathrm{Ca}^{2+}$-imaging experiments. All single-channel currents records were sampled at $10 \mathrm{kHz}$ and filtered online at $5 \mathrm{kHz}$. The displayed single-channel records have been low pass filtered at $1 \mathrm{kHz}$. For the inside-out and cell-attached patch experiments we used higher resistance glass pipettes $(8-12 \mathrm{M} \Omega)$ than in the whole-cell experiments.

DRG neurons were studied using a $\mathrm{CsCl}$ based internal solution [containing (in mM): $140 \mathrm{CsCl}, 1 \mathrm{CaCl}_{2}, 2 \mathrm{MgATP}, 10 \mathrm{EGTA}$, and 10 HEPES, $\mathrm{pH} 7.4(\mathrm{CsOH})]$ to block potassium currents. The external medium contained (in mM) $140 \mathrm{NaCl}, 5 \mathrm{KCl}, 10$ glucose, 10 HEPES, $0.015 \mathrm{CaCl}_{2}$, and $1 \mathrm{MgCl}_{2}$ buffered to $\mathrm{pH} 7.4(\mathrm{NaOH})$. The use of a reduced calcium concentration eliminated significant calcium flux through voltage-gated calcium channels and prevented sodium movements through the calcium channels, which can occur in calcium-free solutions.

The voltage sensitivity of membrane currents were investigated using either a voltage ramp protocol ( $1 \mathrm{~s}$ duration, -100 to $+100 \mathrm{mV}$, CHO cells; or $2 \mathrm{~s},-40$ to +40 or $+60 \mathrm{mV}$, DRG neurons) or depolarizing voltage steps up to $+180 \mathrm{mV}$ followed by repolarization to the holding potential of $-60 \mathrm{mV}$. Because TRPA1-mediated currents showed a rapid inactivation in calcium-containing solutions, measurements of voltage sensitivity were performed in the calcium-free solutions noted above for CHO cells and DRG neurons.

Ninety-six-well plate intracellular calcium concentration assays. In some experiments, changes in intracellular calcium $\left(\left[\mathrm{Ca}^{2+}\right]_{\mathrm{i}}\right)$ were determined in TRPA1 expressing CHO cells grown in 96-well black-walled plates (Costar, Cambridge, MA) using a Flexstation 3 (Molecular Devices). Cells were loaded with Fura 2-AM and assays were performed at $25^{\circ} \mathrm{C}$. Basal emission ratios with excitation wavelengths of 340 and 380 $\mathrm{nm}$ were measured and changes in dye emission ratio determined at various times after compound addition.

Behavioral responses. All animal studies were performed according to the UK Home Office Animal Procedures Act (1986). Data shown are from male and female homozygote trpa $1^{-1-}$ and wild-type littermates. Intraplantar injections of hydrogen peroxide $(0.3 \%$ [ $2.2 \mu \mathrm{mol}]$ in saline $)$ or 15 -deoxy- $\Delta^{12,14}$-prostaglandin $\mathrm{J}_{2}(30 \mathrm{nmol}[10 \mu \mathrm{g}]$ in $10 \% \mathrm{DMSO} /$ saline) were used to induce and compare nocifensive/pain responses in trpa1 $^{-1-}$ and wild-type mice. These doses were based on dose-response relationships for hydrogen peroxide and 15-deoxy- $\Delta^{12,14}$-prostaglandin $\mathrm{J}_{2}$ determined in wild-type mice. Injections $(25 \mu \mathrm{l})$ were made subcutaneously into the plantar surface of one of the hind paws using a $50 \mu \mathrm{l}$ luer-syringe (Hamilton, Reno, NV) fitted with a 26 -gauge by $3 / 8$ inch intradermal needle. Immediately after injection, mice were placed inside a Perspex chamber and the duration of the pain-related behaviors (licking and biting or flinching and shaking of the injected paw) recorded using a digital stop-watch. Observation periods of $1 \mathrm{~min}$ were used and behavior recorded for up to $10 \mathrm{~min}$ after injection. Total pain response times over the first $3 \mathrm{~min}$ were used for analysis as the pain behaviors were largely confined to this period. Groups of six animals were used for each agent.

Drugs. 15-Deoxy- $\Delta^{12,14}$-prostaglandin $\mathrm{J}_{2}$ was from Biomol (Exeter, UK). $\mathrm{PGA}_{2}, 9,10$-dihydro-15d-PGJ, 4 -ONE, 4-HNE, and 4-HHE were obtained from Cayman Chemical (Ann Arbor, MI). Hydrogen peroxide was from VWR International (Lutterworth, UK). All other reagents were from Sigma (Poole, UK).

\section{Results \\ $\mathrm{H}_{2} \mathrm{O}_{2}$ activates TRPA1 in CHO cells Electrophysiology}

$\mathrm{H}_{2} \mathrm{O}_{2}$ evoked an inward current in TRPA1-expressing CHO cells at a holding potential of $-60 \mathrm{mV}$ (Fig. $1 \mathrm{~A}$ ). In contrast, concentrations of $\mathrm{H}_{2} \mathrm{O}_{2}$ up to $100 \mathrm{~mm}$ failed to evoke currents in untransfected CHO cells (data not shown). The time course of the current was influenced by the presence or absence of $\mathrm{Ca}^{2+}$ in the external medium. In $\mathrm{Ca}^{2+}$-free external solutions the current developed slowly and persisted in the continued presence of $\mathrm{H}_{2} \mathrm{O}_{2}$. When $\mathrm{Ca}^{2+}$ was subsequently added to the $\mathrm{H}_{2} \mathrm{O}_{2}-$ containing solution there was a rapid increase in current amplitude, consistent with a calcium-mediated potentiation, followed by a rapid inactivation (Fig. $1 \mathrm{~A}$ ). When $\mathrm{H}_{2} \mathrm{O}_{2}$ was applied in the presence of external $\mathrm{Ca}^{2+}$, the current activated with a concentration-dependent latency and then inactivated. The current occurred with a short latency with high concentrations of $\mathrm{H}_{2} \mathrm{O}_{2}$ but developed after a delay of up to a minute with low concentrations (Fig. $1 \mathrm{~B}$ ). A similar waveform and calcium dependence of TRPA1 mediated currents has been noted with either AITC or cinnamaldehyde as the agonist (Nagata et al., 2005; Doerner et al., 2007).

Under physiological conditions, the cytosol usually contains millimolar concentrations of glutathione, which acts as an antioxidant. It was possible that the intracellular glutathione levels were depleted during whole-cell recording, rendering the cells more sensitive to oxidative agents. Experiments were therefore performed with $10 \mathrm{~mm}$ reduced glutathione in the intracellular, pipette filling solution. Inclusion of exogenous glutathione did 
A
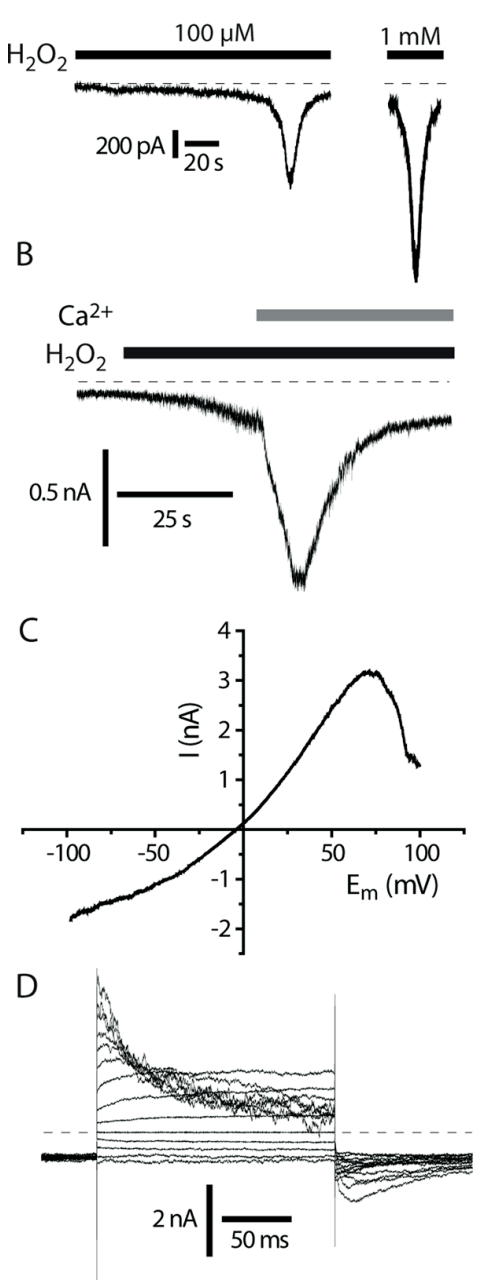

Figure 1. $\mathrm{H}_{2} \mathrm{O}_{2}$ activates TRPA1 expressed in $\mathrm{CH} 0$ cells. $\boldsymbol{A}, \mathrm{H}_{2} \mathrm{O}_{2}$ activates TRPA1 with a concentration-dependent latency in $\mathrm{Ca}^{2+}$-containing solutions. Currents recorded in calciumcontaining solution showing characteristic "threshold" with a sudden increase in membrane current. $\boldsymbol{B}_{1} \mathrm{Ca}^{2+}$ potentiates $\mathrm{H}_{2} \mathrm{O}_{2}$-induced TRPA1 currents. Current response to $10 \mathrm{~mm} \mathrm{H}_{2} \mathrm{O}_{2}$ in a TRPA1 $\mathrm{CHO}$ cell, $-60 \mathrm{mV}$. Note the slow increase in current in calcium-free solution followed by a rapid current increase when $\mathrm{Ca}^{2+}(2 \mathrm{~mm})$ is added. C, Current-voltage relationship of $\mathrm{H}_{2} \mathrm{O}_{2}$-evoked current with $2 \mathrm{~s}$ voltage ramp in a TRPA1 $\mathrm{CH} 0$ cell in calcium-free solution revealed a reduced current at positive potentials. $\boldsymbol{D}$, Kinetics of $\mathrm{H}_{2} \mathrm{O}_{2}$-evoked TRPA1 current in calcium free solution. Note the time and voltage-dependent inactivation at more positive potentials that accounts for reduced conductance seen with voltage ramp protocols (C) (Figs. 2C, 4C). Holding potential $-60 \mathrm{mV}$ with $20 \mathrm{mV}$ interval steps to from -80 to $+180 \mathrm{mV}$.

not reduce the amplitude of the $\mathrm{H}_{2} \mathrm{O}_{2}$ induced current or alter the current waveform (data not shown).

The $\mathrm{H}_{2} \mathrm{O}_{2}$ evoked current had a reversal potential close to 0 $\mathrm{mV}$ (Fig. $1 C$ ) and the current-voltage relationship obtained with ramp changes in voltage showed a characteristic decreased conductance at positive $(>70 \mathrm{mV})$ membrane potentials (Fig. 1C). The reduction in conductance at positive membrane potentials was caused by a time-dependent inactivation that was revealed using a voltage step protocol (Fig. $1 D$ ). In the presence of $\mathrm{H}_{2} \mathrm{O}_{2}$ the current-voltage relationship was linear over the range -80 to $0 \mathrm{mV}$. The outward current showed an initial small, timedependent growth at more positive potentials $(0$ to $+60 \mathrm{mV})$, which was associated with an instantaneous, rapidly decaying inward "tail" current (deactivation) seen when the membrane was repolarized to $-60 \mathrm{mV}$. A similar time-dependent growth at positive membrane potentials and subsequent deactivation on

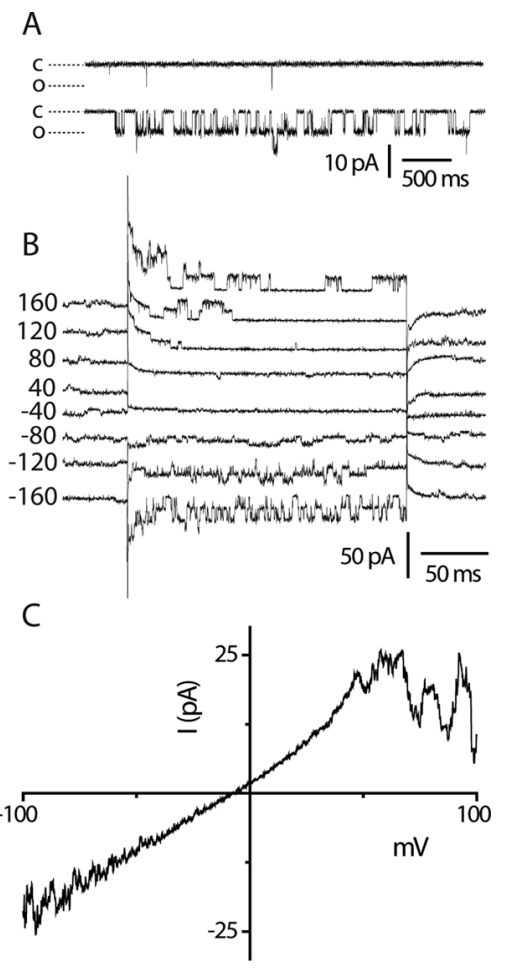

Figure 2. Single-channel activity evoked by $\mathrm{H}_{2} \mathrm{O}_{2}$. Cell attached TRPA1 single-channel currents. $\boldsymbol{A}$, Few brief openings seen in the absence of $\mathrm{H}_{2} \mathrm{O}_{2}$ (top trace), but robust channel activity elicited by $1 \mathrm{~mm} \mathrm{H}_{2} \mathrm{O}_{2}$ (lower trace) at $-100 \mathrm{mV}$. $\boldsymbol{B}$, Voltage-dependent single-channel current activity showing inactivation at positive membrane potentials. Holding potential, $-60 \mathrm{mV}$; traces are offset for clarity. C, Voltage ramp illustrating single-channel inactivation at positive membrane potentials (the trace shown is the average of 5 sweeps).

hyperpolarization has been reported for TRPV1 and TRPM8 in the absence of any added agonists as well in the presence of their respective agonists, capsaicin and menthol (Voets et al., 2004; Nilius et al., 2005). With more positive step potentials ( $\geq+80$ $\mathrm{mV}$ ), the outward current showed an additional time-dependent inactivation during the depolarizing voltage step and the inward tail current seen on repolarization to $-60 \mathrm{mV}$ was more complex with an initial time-dependent growth followed by a decay (deactivation) to the initial holding current (Fig. 1D). The simplest explanation for these observations is that the TRPA1 channels continue to show a time-dependent increase in open probability at the more positive membrane potentials but this is overlaid by a block of the ion channels by some unknown mechanism. The growth in the tail current on repolarization probably represents unblocking of the channels, which then close. Very similar voltage-dependent properties were seen with AITC-evoked currents (supplemental Fig. 1, available at www.jneurosci.org as supplemental material).

A voltage-dependent inactivation of the $\mathrm{H}_{2} \mathrm{O}_{2}$-evoked currents at positive membrane potentials was also evident in $\mathrm{H}_{2} \mathrm{O}_{2}$ evoked single-channel currents recorded in membrane attached patches (Fig. 2A-C). A single-channel chord conductance of $94 \pm 3 \mathrm{pS}$ was noted over the voltage range -100 to $+100 \mathrm{mV}$. The single-channel current activity was clearly reduced at the more positive potentials, but no reduction in single-channel conductance was noted.

Measurements of $\left[\mathrm{Ca}^{2+}\right]_{i}$

We used agonist-evoked changes in $\left[\mathrm{Ca}^{2+}\right]_{\mathrm{i}}$ to quantify the effects of TRPA1 ligands. $\mathrm{H}_{2} \mathrm{O}_{2}$ evoked an increase in $\left[\mathrm{Ca}^{2+}\right]_{\mathrm{i}}$ in 
TRPA1-expressing $\mathrm{CHO}$ cells but not in untransfected $\mathrm{CHO}$ cells or in cells expressing TRPV1, TRPV4, or TRPM8 (data not shown). The effect of $\mathrm{H}_{2} \mathrm{O}_{2}$ was timeand concentration-dependent with larger and faster responses seen at higher $\mathrm{H}_{2} \mathrm{O}_{2}$ concentrations (Fig. 3A). Concentrationresponse curves obtained using changes in $\left[\mathrm{Ca}^{2+}\right]_{\mathrm{i}}$ as an index of channel activation yielded an $\mathrm{EC}_{50}$ value of $230 \mu \mathrm{M}$ after $600 \mathrm{~s}$ exposure to $\mathrm{H}_{2} \mathrm{O}_{2}$ when the responses to each concentration had reached a plateau (Fig. $3 B$ ). The time dependence of the response is illustrated in Figure $3 C$ where the time to half maximal response at each concentration is plotted against $\mathrm{H}_{2} \mathrm{O}_{2}$ concentration. Higher $\mathrm{EC}_{50}$ concentrations were calculated after shorter exposure times and an $\mathrm{EC}_{50}$ value of $1.2 \pm 0.4 \mathrm{~mm}$ was estimated after $90 \mathrm{~s}$ exposure (Fig. 3B).

$\mathrm{H}_{2} \mathrm{O}_{2}$ can act on some proteins via the production of $\mathrm{OH}^{\bullet}$ radicals, which are generated at an accelerated rate when the intracellular concentration of iron is raised because $\mathrm{Fe}^{2+}$ acts as a catalyst in the Fenton reaction. We therefore examined the $\mathrm{H}_{2} \mathrm{O}_{2}$ sensitivity of TRPA1 expressing cells that had been preloaded with $\mathrm{FeSO}_{4}$ (Fig. $3 D)$. The $\mathrm{EC}_{50}$ value in $\mathrm{Fe}^{2+}$-loaded cells (53 $\pm 6 \mu \mathrm{M}$, after $90 \mathrm{~s}$ ) was $\sim 20$-fold lower than in untreated cells, which indicates that $\mathrm{H}_{2} \mathrm{O}_{2}$ exerts its effect, at least in part, by the generation of intracellular $\mathrm{OH}^{\bullet}$ (Fig. 3D). TRPA1 was also activated by 5 $\mu \mathrm{M}$ Rose Bengal, which generates another reactive oxygen species (ROS), singlet oxygen, and by the oxidizing agent chloramine T (supplemental Fig. 2, available at www. jneurosci.org as supplemental material).

\section{$\mathrm{H}_{2} \mathrm{O}_{2}$ activates TRPA1-expressing sensory neurons}

We examined whether $\mathrm{H}_{2} \mathrm{O}_{2}$ stimulated isolated sensory neurons using changes in intracellular free $\mathrm{Ca}^{2+}$ concentration $\left(\left[\mathrm{Ca}^{2+}\right]_{\mathrm{i}}\right)$ as an indicator of neuronal activation. $\mathrm{H}_{2} \mathrm{O}_{2}$ evoked a robust increase in $\left[\mathrm{Ca}^{2+}\right]_{\mathrm{i}}$ in $\sim 25 \%$ of rat DRG neurons, which typically were of small diameter $(20-25 \mu \mathrm{m})$ (Fig. 4A). In whole-cell voltage-clamp experiments on DRG neurons, $\mathrm{H}_{2} \mathrm{O}_{2}$ evoked an inward current at $-60 \mathrm{mV}$ and increased membrane conductance (Fig. $4 B$ ). When the inward current was allowed to develop in solutions containing $15 \mu \mathrm{M} \mathrm{Ca}^{2+}$, subsequent addition of 2 $\mathrm{mM} \mathrm{Ca}{ }^{2+}$ rapidly inactivated the current (Fig. $4 B$ ). Using the same solutions, a similar current inactivation (without the surge in current shown in Fig. $1 \mathrm{~B}$ ) was evident in TRPA1 CHO cells when $2 \mathrm{mM} \mathrm{Ca}^{2+}$ was added (data not shown). A voltage ramp protocol revealed that the $\mathrm{H}_{2} \mathrm{O}_{2}$-evoked current had a reversal potential close to $0 \mathrm{mV}(-6 \mathrm{mV})$, which suggested that the response was mediated by a nonselective cation channel, such as one of the TRP channels. The current-voltage relationship showed a characteristic reduction in conductance at positive membrane potentials similar to that seen for TRPA1 in CHO cells (Fig. 4C), but markedly different from the behavior of TRPV1-4 and TRPM8 mediated currents which do not exhibit any current inactivation at membrane potentials up to $+200 \mathrm{mV}$ (Nilius et al., 2005).
B

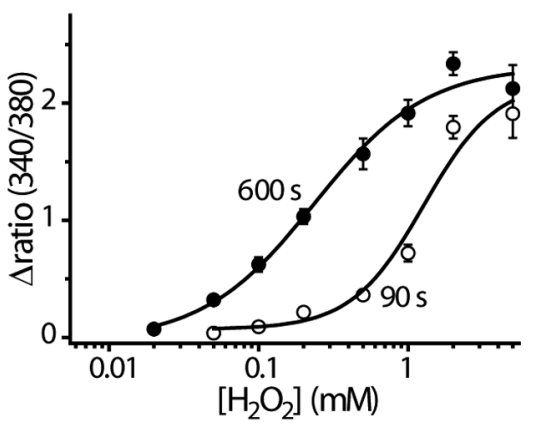

D

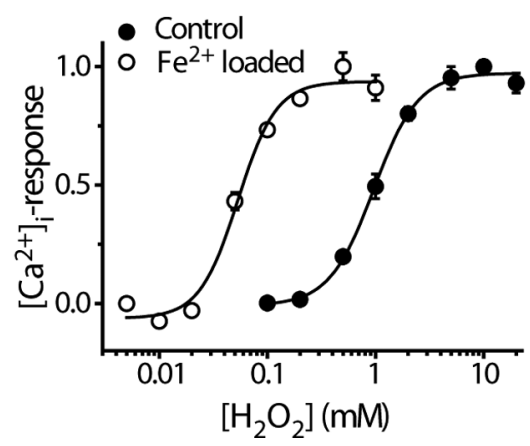

$\left[\mathrm{H}_{2} \mathrm{O}_{2}\right](\mathrm{mM})$

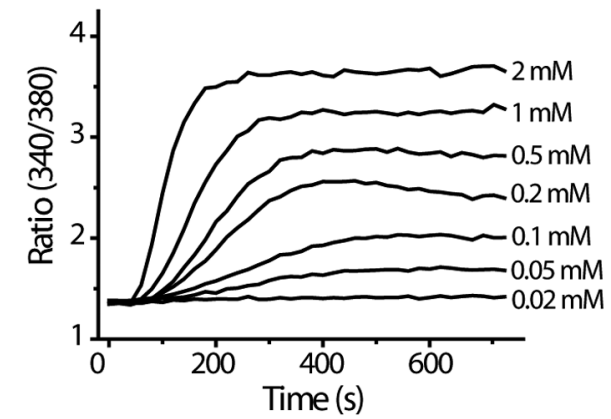

D

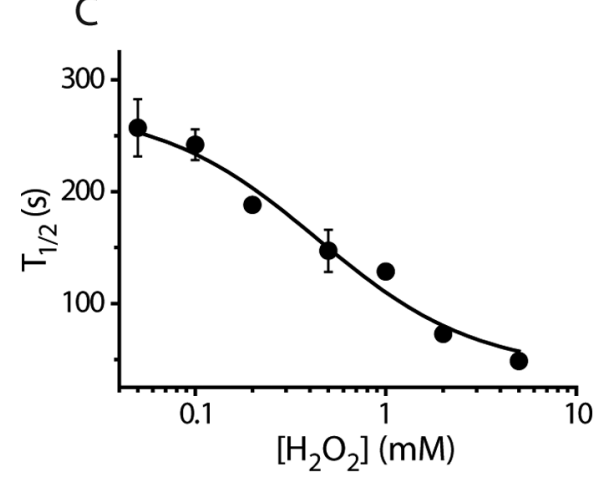

Figure 3. Concentration-dependent effect of $\mathrm{H}_{2} \mathrm{O}_{2}$ on TRPA1. $A$, Concentration-dependent time course of $\left[\mathrm{Ca}^{2+}\right]_{\mathrm{i}}$-responses 列 incubated with $100 \mu \mathrm{m} \mathrm{FeSO}{ }_{4}$ for $1 \mathrm{~h}$ and then washed so that no extracellular $\mathrm{FeSO}_{4}$ was present during the experiment (mean \pm

To gain an insight into the molecular identity of the $\mathrm{H}_{2} \mathrm{O}_{2}-$ activated channels in the native cells, we used changes in $\left[\mathrm{Ca}^{2+}\right]_{\mathrm{i}}$ to examine the responses of rat DRG and nodose neurons to a sequence of agonists that activate different TRP channels and differentiate subpopulations of DRG neurons. In initial experiments, we found no correspondence between $\mathrm{H}_{2} \mathrm{O}_{2}-$ and menthol-sensitivity $(100 \mu \mathrm{M})$, which was expected given the relatively low percentage $(\sim 8 \%)$ of menthol sensitive DRG neurons in DRG cultures (Andersson et al., 2007). Therefore, for most experiments we used AITC and capsaicin to activate TRPA1 and TRPV1, respectively. Any cell responding to a given stimulus with a $\left[\mathrm{Ca}^{2+}\right]_{\mathrm{i}}$-increase of at least $15 \%$ of the response to a subsequent challenge with $50 \mathrm{~mm} \mathrm{KCl}$, was considered "positive." There was a striking correspondence between $\mathrm{H}_{2} \mathrm{O}_{2}$ - and AITC-sensitive neurons (Fig. 4E). This was evident from the very similar percentage of DRG neurons responding to these agents $\left(\mathrm{H}_{2} \mathrm{O}_{2}, 25.1 \%\right.$; AITC, $24.4 \%$ in DRG neurons; $\mathrm{H}_{2} \mathrm{O}_{2}, 49.8 \%$; AITC, $54.0 \%$ in nodose neurons) and from investigations of the chemosensitivities of individual neurons. All the $\mathrm{H}_{2} \mathrm{O}_{2}$-sensitive DRG neurons responded to AITC and treatment with AITC always occluded the response to a subsequent challenge with $\mathrm{H}_{2} \mathrm{O}_{2}$. As TRPA1 is expressed in a subpopulation of TRPV 1 neurons we found neurons that responded to both $\mathrm{H}_{2} \mathrm{O}_{2}$ and capsaicin but $\sim 50 \%$ of capsaicin-sensitive DRG neurons and $\sim 30 \%$ of capsaicinsensitive nodose neurons did not respond to $\mathrm{H}_{2} \mathrm{O}_{2}$ (Fig. $4 D, E)$. Furthermore, the proportion of $\mathrm{H}_{2} \mathrm{O}_{2}$-sensitive DRG neurons was unchanged in trpv1 $1^{-/-}$mice $(31.8 \%, 113$ of 355$)$ 
A
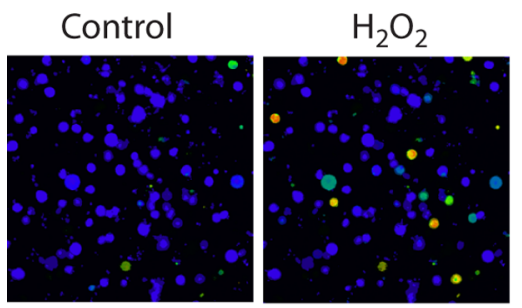

C

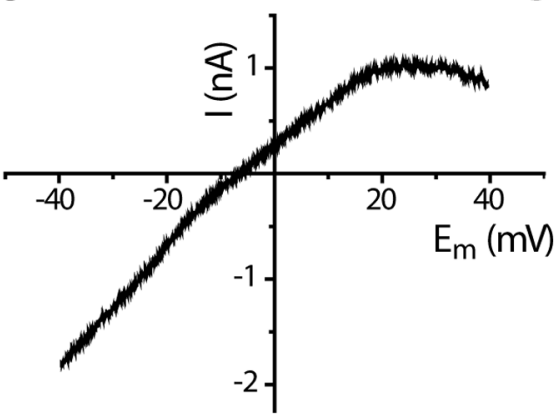

B

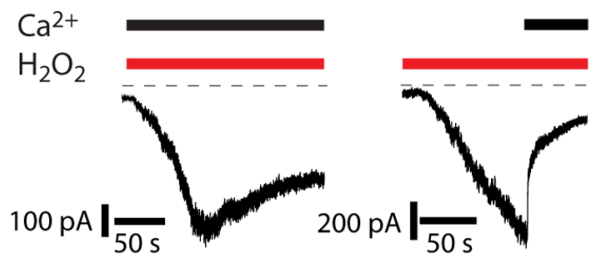

D

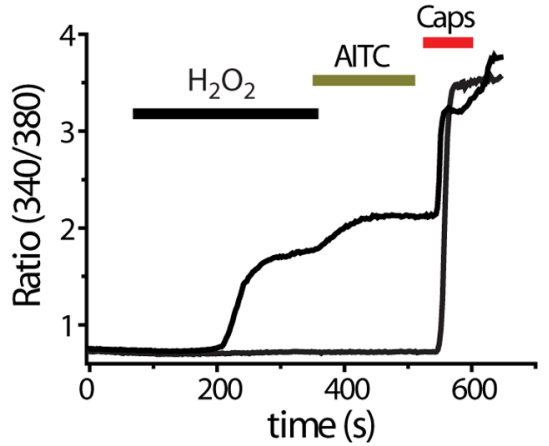

E

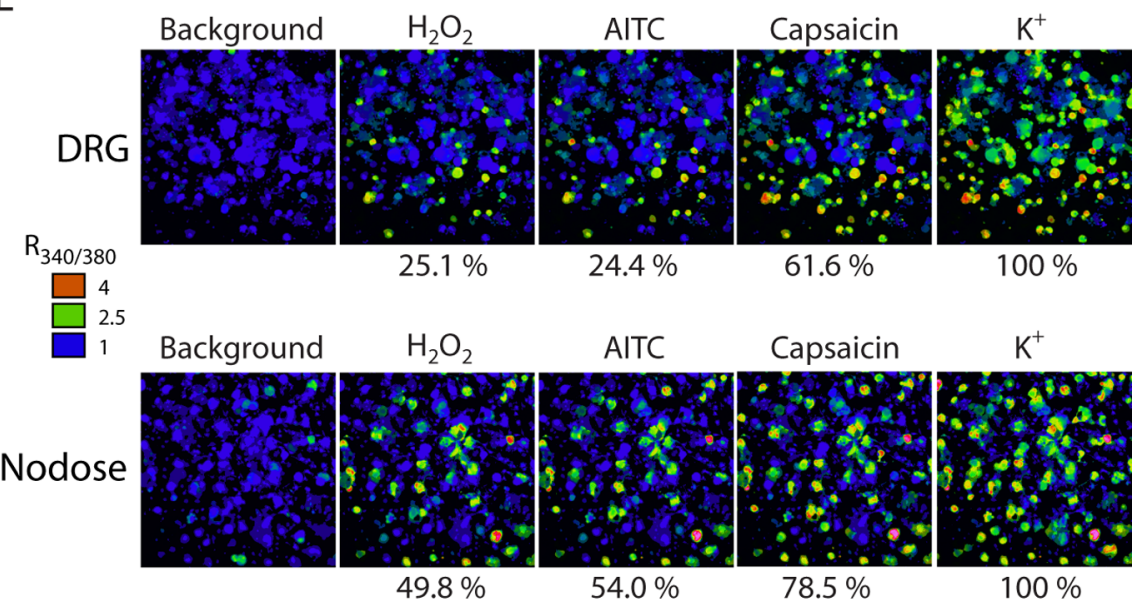

Figure 4. $\mathrm{H}_{2} \mathrm{O}_{2}$ activates TRPA1-containing DRG and nodose neurons. $A$, Pseudocolored images illustrating $\left[\mathrm{Ca}^{2+}\right]_{\mathrm{i}}$ responses evoked by $\mathrm{H}_{2} \mathrm{O}_{2}(5 \mathrm{~mm})$ measured with Fura- 2 in rat DRG neurons. $\boldsymbol{B}$, Currents evoked by $\mathrm{H}_{2} \mathrm{O}_{2}(1 \mathrm{~mm})$ in DRG neurons in the presence (left) and absence (right) of extracellular calcium (at a holding potential of $-60 \mathrm{mV}$ ). The current rapidly inactivated when $\mathrm{Ca}^{2+}$ was applied after an initial current has developed in $\mathrm{Ca}^{2+}$-free conditions. C, Current-voltage plot for the $\mathrm{H}_{2} \mathrm{O}_{2}$ response in a DRG neuron generated by a slow $2 \mathrm{~s}$ voltage ramp in $\mathrm{Ca}^{2+}$-free solution. Note the characteristic reduced conductance at positive membrane potential. $\boldsymbol{D}$, Change in $\left[\mathrm{Ca}^{2+}\right]_{\mathrm{i}}(340 / 380$ ratio) of typical DRG neurons in response to sequential applications of $\mathrm{H}_{2} \mathrm{O}_{2}$, AITC, and capsaicin (Caps) showing $\mathrm{H}_{2} \mathrm{O}_{2}$-sensitive and $\mathrm{H}_{2} \mathrm{O}_{2}$-insensitive TRPV1 expressing neurons. $\boldsymbol{E}$, $\left[\mathrm{Ca}^{2+}\right]_{\mathrm{i}}$ responses in DRG (top sequence) and nodose neurons (bottom sequence) to sequential application of $\mathrm{H}_{2} \mathrm{O}_{2}(5 \mathrm{~mm})$, AITC $(50 \mu \mathrm{M})$, and capsaicin $(1 \mu \mathrm{M})$. All neurons in the culture were identified by the $\left[\mathrm{Ca}^{2+}\right]_{\mathrm{i}}$ increase elicited by application of $50 \mathrm{~mm}$ $\mathrm{K}^{+} . \mathrm{H}_{2} \mathrm{O}_{2}$, AlTC and capsaicin stimulated a larger proportion of neurons dissociated from nodose than dorsal root ganglia. The number of neurons tested in each group was between 363 and 744 .

compared with wild-type mice $(30.1 \%, 134$ of 445$)$, ruling out TRPV1 as a mediator of DRG $\mathrm{H}_{2} \mathrm{O}_{2}$ responses.

\section{TRPA1 is activated by products of lipid peroxidation}

Oxidative stress generates other reactive chemicals, including products of lipid peroxidation, some of which have an electrophilic $\alpha, \beta$-unsaturated carbonyl moiety like that found in the TRPA1 agonist, cinnamaldehyde. We therefore examined the effects on TRPAl of three major lipids produced during episodes of oxidative stress (Uchida, 2003): 4-HNE, 4-HHE, and 4-ONE.

In calcium imaging experiments, 4-HNE $(30 \mu \mathrm{M})$ and $4-\mathrm{ONE}$

$(3 \mu \mathrm{M})$ increased $\left[\mathrm{Ca}^{2+}\right]_{\mathrm{i}}$ in $\sim 25 \%$ of DRG neurons, similar to the percentage that responded to AITC or $\mathrm{H}_{2} \mathrm{O}_{2}$. Approximately $50 \%$ of the capsaicin-sensitive neurons responded to 4-HNE and 4-ONE and there was an exact correspondence between the 4-HNE/4-ONE responsive and AITC sensitive neurons (Fig. $5 A$ ). This pattern suggests that TRPA1 mediates the response to 4-HNE and 4-ONE in DRG neurons.

To examine the effects of 4-HNE on TRPA1 further, we studied its effect on heterologously expressed channels. 4-HNE evoked membrane currents and a robust $\left[\mathrm{Ca}^{2+}\right]_{\mathrm{i}}$ increase in TRPA1 CHO cells, but not in untransfected cells or in TRPV1 expressing $\mathrm{CHO}$ cells (data not shown). The characteristics of the TRPA1-evoked currents were similar, although not identical, to those found with AITC or $\mathrm{H}_{2} \mathrm{O}_{2}$ activation (Fig. 5B). A relatively sustained current developed after several seconds delay in a $\mathrm{Ca}^{2+}$-free external solution. Addition of $\mathrm{Ca}^{2+}$ evoked a sudden decrease in current, not seen with the other agonists, followed by a transient increase in current and rapid inactivation.

In DRG neurons, application of 4-HNE evoked a sustained inward current in solutions containing $15 \mu \mathrm{M} \mathrm{Ca}{ }^{2+}$. Furthermore, the 4-HNE current showed a voltage-dependent inactivation at positive membrane potentials as shown by the current responses to a voltage ramp in TRPA1 expressing $\mathrm{CHO}$ cells and DRG neurons (Fig. 5B,C). These results are consistent with the independent previous reports by two other groups that 4-HNE activates TRPA1 (Macpherson et al., 2007b; Trevisani et al., 2007).

All three lipid peroxidation products tested (4-HHE, 4-HNE, and 4-ONE) evoked increases in $\left[\mathrm{Ca}^{2+}\right]_{\mathrm{i}}$ in TRPA1expressing $\mathrm{CHO}$ cells (Fig. 6A). Concentration-response curves for the agonist induced increases in $\left[\mathrm{Ca}^{2+}\right]_{i}$ (Fig. 6A) revealed that 4 -HHE and 4 -HNE were approximately equipotent $\left(\mathrm{EC}_{50}\right.$ values: 4-HNE, $19.9 \pm 2.7 \mu \mathrm{M}$; 4-HHE, $39.9 \pm$ $12.0 \mu \mathrm{M})$ whereas 4 -ONE was more potent $\left(\mathrm{EC}_{50}\right.$ value, $\left.1.9 \pm 0.7 \mu \mathrm{M}\right)$. These $\mathrm{EC}_{50}$ values are consistent with the greater thiol reactivity of 4-ONE (Lin et al., 2005).

Cyclopentenone prostaglandins are TRPA1 agonists $15 \mathrm{~d}-\mathrm{PGJ}_{2}$ is a major cyclopentenone prostaglandin produced nonenzymatically by dehydration of the labile prostaglandin, $\mathrm{PGD}_{2}$. The electrophilic $15 \mathrm{~d}-\mathrm{PGJ}_{2}$ is thiol reactive, induces intracellular production of reactive oxygen species and contributes to oxidative stress (Kondo et al., 2001; Levonen et al., 2004). In calcium-imaging experiments, we found that $20 \mu \mathrm{M} 15 \mathrm{~d}-\mathrm{PGJ}_{2}$ elicited an increase in $\left[\mathrm{Ca}^{2+}\right]_{\mathrm{i}}$ in AITC-sensitive DRG neurons (Fig. 5A). To investigate whether $15 \mathrm{~d}_{-}-\mathrm{PGJ}_{2}$ could activate 
TRPA1, we examined the effects of $15 \mathrm{~d}$ $\mathrm{PGJ}_{2}$ on TRPA1 CHO cells. 15d-PGJ ${ }_{2}$ evoked inward currents and an increase in $\left[\mathrm{Ca}^{2+}\right]_{\mathrm{i}}$ in TRPA1 CHO cells (Fig. 5D), but had no effect on either TRPV1 or untransfected CHO cells (data not shown). The effect of $15 \mathrm{~d}-\mathrm{PGJ}_{2}$ was concentration dependent with an $\mathrm{EC}_{50}$ value of $5.6 \pm 1.1 \mu \mathrm{M}$ calculated from increases in $\left[\mathrm{Ca}^{2+}\right]_{\mathrm{i}}$ (Fig. $6 A)$. Importantly, the structurally related, but chemically less-reactive analogs 9,10dihydro-15d-PGJ ${ }_{2}$ and $\mathrm{PGA}_{2}$ failed to elicit any significant $\left[\mathrm{Ca}^{2+}\right]_{\mathrm{i}}$-increase at concentrations $<50 \mu \mathrm{M}$ (data not shown).

\section{Reversibility of TRPA1 activation}

by DTT

Reactive oxygen species and the lipid activators of TRPA1 are able to modify cysteine, lysine, and histidine residues. $\mathrm{H}_{2} \mathrm{O}_{2}$ may promote the formation of disulfide bonds between cysteine residues, whereas the lipid activators are likely to form Michael adducts and may cross-link vicinal reactive groups. We therefore examined whether the effects of these agonists could be reversed by dithiothreitol (DTT) (1 mM), which will reduce disulfide bonds but is unable to hydrolyze Michael adducts. DTT reversed the effects of $\mathrm{H}_{2} \mathrm{O}_{2}$, but not the responses to 4 -HNE or $15 \mathrm{~d}-\mathrm{PGJ}_{2}$ (Fig. 6B).

Effect of $\mathrm{H}_{2} \mathrm{O}_{2}, 4-\mathrm{ONE}$, and 15d-PGJ ${ }_{2}$ on TRPA1 in isolated patches

Compounds with electrophilic or oxidative properties are likely to modify the activity of many cellular proteins and processes in addition to TRPA1. To examine the possibility that the novel endogenous ligands activate TRPA1 by interacting with cytoplasmic proteins, we investigated whether $\mathrm{H}_{2} \mathrm{O}_{2}, 4-\mathrm{ONE}$, and $15-\mathrm{PGJ}_{2}$ were able to activate TRPA1 in isolated inside-out membrane patches. As shown in Figure 7, application of $\mathrm{H}_{2} \mathrm{O}_{2}$ (Fig. 7A), 4-ONE (Fig. $7 B$ ), and $15 \mathrm{~d}-\mathrm{PGJ}_{2}$ (Fig. 7C) opened TRPA1 channels in isolated inside-out patches, consistent with a membranedelimited site of action that is not dependent on cytosolic mechanisms. In some patches, we noted that TRPA1 could be repeatedly activated and inactivated by $\mathrm{H}_{2} \mathrm{O}_{2}$ and DTT, respectively, further suggesting a direct action of these compounds on the channel (supplemental Fig. 3, available at www.jneurosci.org as supplemental material)

Effects of oxidative stress products on DRG neurons from $\operatorname{trpa1}^{-/-}$mice

The correspondence between AITC-sensitivity and sensitivities to $\mathrm{H}_{2} \mathrm{O}_{2}, 4-\mathrm{HNE}, 4-\mathrm{ONE}$ and $15 \mathrm{~d}-\mathrm{PGJ}_{2}$ in DRG neurons and the abilities of these agents to activate TRPA1 in CHO cells is consis-

B

C $15 \mathrm{~d}-\mathrm{PGJ} \mathrm{F}_{2}$-evoked current.
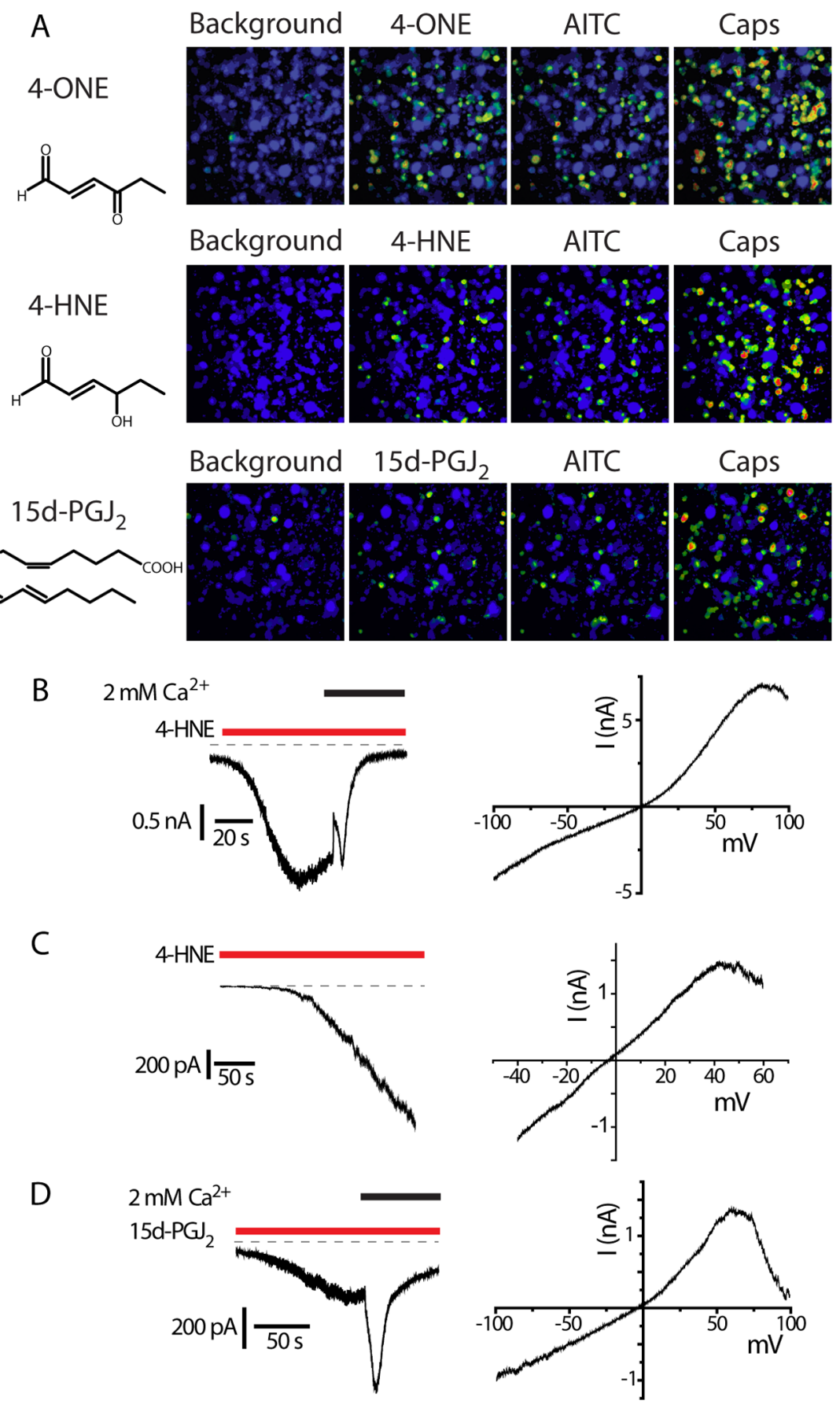

Figure 5. Lipid peroxidation products and $15 \mathrm{~d}-\mathrm{PG} \mathrm{J}_{2}$ are TRPA 1 agonists. $A,\left[\mathrm{Ca}^{2+}\right]_{\mathrm{i}}$ increases evoked by $4-0 \mathrm{NE}(3 \mu \mathrm{M}), 4-\mathrm{HNE}$ $(30 \mu \mathrm{M})$, and 15d-PGJ $2(20 \mu \mathrm{M})$ in DRG neurons. Sequential applications of AITC and capsaicin (Caps) show that 4-ONE, 4-HNE, and 15d-PGJ ${ }_{2}$ activate the same subset of TRPV1-expressing, capsaicin-sensitive neurons as AITC. B, Left, 4-HNE-evoked current in a TRPA1 CHO cell initially in calcium-free solution. Admission of calcium led to rapid inactivation. Right, Current-voltage relationship of 4-HNE-evoked current. C, Left, 4-HNE-evoked current in a DRG neuron (external solution containing $15 \mu \mathrm{m} \mathrm{Ca}{ }^{2+}$, $-60 \mathrm{mV}$ ). Right, Current-voltage relationship of the 4-HNE-evoked current in the same neuron. $\boldsymbol{D}$, Time course (left) and voltage-dependent kinetics (right) for $15 \mathrm{~d}-\mathrm{PGJ}$-evoked TRPA1 current in a $\mathrm{CHO}$ cell. Right, Current-voltage relationship of

tent with TRPA1 acting as the neuronal sensor. To confirm this hypothesis we examined the responses of DRG neurons from wild-type and TRPA1-null allele mutant mice using calcium imaging. The results of these experiments are shown in Table 1 . The percentage of responsive DRG neurons from wild-type mice was very similar to the percentages seen for rat DRG neurons. First, we confirmed the loss of TRPA1 in the $\operatorname{trpa1}^{-/-}$DRG neurons 
A
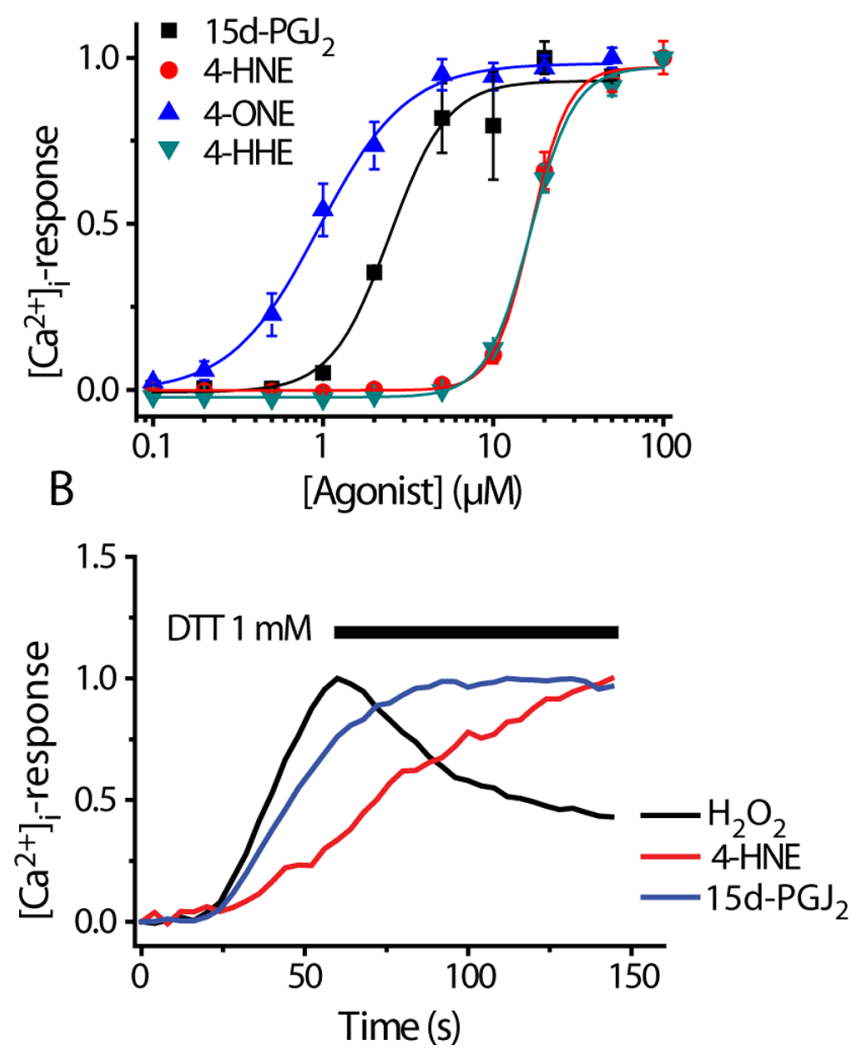

Figure 6. Concentration dependence of lipid mediators and dithiothreitol sensitivity. $\boldsymbol{A}$, Concentration-response curves for 4-0NE, 4-HNE, 4-HHE, and 15d-PGJ in TRPA1 CHO cells (mean $\pm \mathrm{SEM}, n=4$, representative of at least 3 experiments). $\boldsymbol{B}$, Application of DTT reverse $\left[\mathrm{Ca}^{2+}\right]_{\mathrm{i}}$-responses induced by application of $\mathrm{H}_{2} \mathrm{O}_{2}$, but not 4-HNE or $15 \mathrm{~d}-\mathrm{PG} \mathrm{J}_{2}$.

using AITC as an agonist. Robust responses were noted in neurons from wild-type mice but responses to AITC were largely absent in trpa1 ${ }^{-1-}$ mouse neurons as previously described (Kwan et al., 2006; Macpherson et al., 2007b). Similarly, the responses to $\mathrm{H}_{2} \mathrm{O}_{2}, 4-\mathrm{HNE}$, 4-ONE, and $15 \mathrm{~d}-\mathrm{PGJ}_{2}$ were essentially eliminated in the DRG neurons from knock-out mice. When present, the residual responses in $\operatorname{trpa} 1^{-1-}$ neurons were usually slow in onset, small and showed oscillating changes in $\left[\mathrm{Ca}^{2+}\right]_{i}$, unlike the sustained responses in wild-type neurons.

\section{$\mathrm{H}_{2} \mathrm{O}_{2}$ and 15d-PGJ ${ }_{2}$ produce pain-related behavior through activation of TRPA1}

We examined whether TRPA1 is required for pain responses elicited by $\mathrm{H}_{2} \mathrm{O}_{2}$ and $15 \mathrm{~d}-\mathrm{PGJ}_{2}$ in vivo. Intraplantar injections of either compound evoked dose-dependent pain related behaviors in wild-type mice (licking, biting, flinching or shaking of the injected paw) that lasted for at least $3 \mathrm{~min}$ after injection (Fig. $8 A, B)$. Doses that evoked reproducible robust responses were used to test the effects on $\operatorname{trpa1} 1^{-/-}$mice and wild-type littermates. Injections of either $2.2 \mu \mathrm{mol}$ of $\mathrm{H}_{2} \mathrm{O}_{2}$ or $32 \mathrm{nmol}$ of $15 \mathrm{~d}$ $\mathrm{PGJ}_{2}$ (in $25 \mu \mathrm{l}$ ) induced marked nocifensive behaviors in wildtype mice that were greatly reduced or absent in $\operatorname{trpa1} 1^{-1-}$ mice (Fig. 8C,D).

\section{Discussion}

Our results demonstrate that reactive oxygen species, alkenyl aldehydes and $15 \mathrm{~d}-\mathrm{PGJ}_{2}$, which are generated during oxidative stress, activate TRPA1 in sensory neurons. All the agents acti- vated TRPA1 expressed in CHO cells and evoked increases in $\left[\mathrm{Ca}^{2+}\right]_{\mathrm{i}}$ in $\sim 50 \%$ of capsaicin sensitive DRG neurons. There was a close correspondence between the sensitivity of individual sensory neurons to the known TRPA1 agonist, AITC, and responsiveness to either $\mathrm{H}_{2} \mathrm{O}_{2}, 4-\mathrm{HNE}, 4-\mathrm{ONE}$, or $15 \mathrm{~d}-\mathrm{PGJ}_{2}$. Importantly, the responses to $\mathrm{H}_{2} \mathrm{O}_{2}, 4-\mathrm{HNE}, 4-\mathrm{ONE}$, and $15 \mathrm{~d}-\mathrm{PGJ} \mathrm{J}_{2}$ were almost absent in DRG neurons from trpa1 ${ }^{-1-}$ mice. Furthermore, our in vivo experiments with trpa1 ${ }^{-1-}$ mice demonstrated that TRPA1 was required for the pain-related behavioral responses evoked by $\mathrm{H}_{2} \mathrm{O}_{2}$ and $15 \mathrm{~d}-\mathrm{PG} \mathrm{J}_{2}$.

Several studies have suggested that TRPV1 mediates the sensory neuron responses to $\mathrm{H}_{2} \mathrm{O}_{2}$ (Schultz and Ustinova, 1998; Ruan et al., 2005, 2006; Yoshida et al., 2006). However, the mismatch between $\mathrm{H}_{2} \mathrm{O}_{2}$ - and capsaicin-sensitivity and the loss of $\mathrm{H}_{2} \mathrm{O}_{2}$ responses in trpa1 ${ }^{-1-}$ mice indicate that TRPV1 is not primarily responsible for $\mathrm{H}_{2} \mathrm{O}_{2}$ activation of sensory nerve fibers. Unlike Yoshida et al. (2006), we found no evidence for direct activation of TRPV1 by $\mathrm{H}_{2} \mathrm{O}_{2}$ in our experiments. Furthermore, we observed no loss of $\mathrm{H}_{2} \mathrm{O}_{2}$ responses in DRG neurons from mice lacking TRPV1 ruling out the possibility that responses to $\mathrm{H}_{2} \mathrm{O}_{2}$ are mediated by a splice variant of TRPV1.

TRPA1 activation by $\mathrm{H}_{2} \mathrm{O}_{2}$ is likely to be an important pathway for neuronal stimulation in vivo. Single-unit recording from afferent nerve fibers innervating the heart showed that $\sim 50 \%$ of capsaicin sensitive units were activated by $\mathrm{H}_{2} \mathrm{O}_{2}$ via production of $\mathrm{OH}^{\bullet}$ (Ustinova and Schultz, 1994). This corresponds well with our findings that a similar percentage of isolated, capsaicin sensitive DRG neurons were activated by $\mathrm{H}_{2} \mathrm{O}_{2}$ in calcium imaging experiments and that activation was, at least in part, mediated by $\mathrm{OH}^{\bullet}$ radicals.

The finding that $\mathrm{H}_{2} \mathrm{O}_{2}, 4-\mathrm{HNE}$, or $15 \mathrm{~d}-\mathrm{PGJ}_{2}$ activated TRPA1 in isolated membrane patches is consistent with direct chemical modification of TRPA1, although we cannot rule out effects on closely associated interacting proteins. Six cysteine residues located in the $\mathrm{N}$-terminal segment have been identified as potential sites for oxidation and activation of TRPA1 by exogenous electrophilic reagents (AITC, cinnamaldehyde), whereas other molecular mechanisms appear to operate for agonists such as icilin and THC (Hinman et al., 2006; Macpherson et al., 2007a). DTT, which can reduce disulphide bonds but does not affect Michael adducts (Macpherson et al., 2007a), did not affect the responses to 4 -HNE or $15 \mathrm{~d}-\mathrm{PGJ}_{2}$, suggesting that these lipid mediators form covalent adducts with TRPA1. This conclusion is consistent with reports that the actions of $15 \mathrm{~d}-\mathrm{PGJ}_{2}$ on Kelch-like ECHassociated protein 1 (KEAP1) and peroxisome proliferatoractivated receptor- $\gamma$ (PPAR- $\gamma$ ) are exerted by Michael additions to redox-sensitive cysteine thiols and that 4-HNE and 4-ONE form adducts with cysteine residues (Shibata et al., 2003; Levonen et al., 2004; Sayre et al., 2006). The finding that DTT reversed the effects of $\mathrm{H}_{2} \mathrm{O}_{2}$ indicates the formation of disulfide bonds between vicinal cysteine residues. Although actions on cysteine residues in TRPA1 are therefore likely, it is premature to conclude that all the effects reported in this study result exclusively from cysteine modifications. Hinman et al. (2006) showed that one lysine residue (K708) also influenced the activity of AITC. The alkenyl aldehydes studied here preferentially react with cysteine residues (Petersen and Doorn, 2004), but can also form Michael adducts with histidine, and 4-ONE has been reported to form a Schiff base with $\varepsilon$-amino groups of lysine residues (Lin et al., 2005). In TRPA1 CHO cells the waveform of the membrane currents evoked by increasing the extracellular $\mathrm{Ca}^{2+}$ concentration from $\mathrm{Ca}^{2+}$-free to $2 \mathrm{mM} \mathrm{Ca}^{2+}$ were agonist dependent. The current suddenly increased and then inactivated with $\mathrm{H}_{2} \mathrm{O}_{2}, 15$ d- 
$\mathrm{PGJ}_{2}$, or AITC as the agonist, whereas with 4-HNE, the current showed a sudden decrease before increasing and then inactivating. These findings suggest some agonist-dependent differences in the interactions with TRPA1. Identification of the residues and mechanisms responsible for TRPA1 activation by $\mathrm{H}_{2} \mathrm{O}_{2}$, alkenyl aldehydes and $15 \mathrm{~d}-\mathrm{PGJ}_{2}$ remains to be explored.

Our studies show that $\mathrm{H}_{2} \mathrm{O}_{2}$ and $15 \mathrm{~d}$ $\mathrm{PGJ}_{2}$ activate sensory neurons in vivo to evoke pain responses. The responses were almost completely absent in trpa1 ${ }^{-/-}$ mice, demonstrating that sensory stimulation by these agents was mediated by TRPA1. These results complement the previous finding that 4 -HNE evokes pain responses by activating TRPA1 (Trevisani et al., 2007). The concentrations of $\mathrm{H}_{2} \mathrm{O}_{2}$, 4-HNE, and $15 \mathrm{~d}-\mathrm{PGJ}_{2}$ required to stimulate TRPA1 and pain responses are higher than those that normally occur in tissues, but all the agents are produced at much higher concentrations during periods of oxidative stress.

NADPH oxidase-derived ROS, such as $\mathrm{H}_{2} \mathrm{O}_{2}$, have been proposed to play a role in local cell signaling by affecting the function of various kinases, phosphatases, phospholipases, and transcription factors, at low submicromolar concentrations (Lambeth, 2004; Bedard and Krause, 2007). ROS occur at higher concentrations in conditions of oxidative stress when their production exceeds the antioxidant activity of the cell. $\mathrm{H}_{2} \mathrm{O}_{2}$ concentrations of $10-100 \mu \mathrm{M}$ have been measured in situations of physiological stress such as inflammation and reperfusion after ischemia (Hyslop et al., 1995; Sprong et al., 1997; Stone and Yang, 2006), which is similar to concentrations that activate TRPA1 $(50-100 \mu \mathrm{M})$. The intracellular $\mathrm{H}_{2} \mathrm{O}_{2}$ concentration is probably 7-10 times lower than the extracellularly applied concentration (Stone and Yang, 2006), suggesting that TRPA1 can be activated when the intracellular $\mathrm{H}_{2} \mathrm{O}_{2}$ concentration reaches tens of micromolar. TRPA1 activation may be mediated directly by $\mathrm{H}_{2} \mathrm{O}_{2}$, but the finding that the potency of $\mathrm{H}_{2} \mathrm{O}_{2}$ was increased by 20 -fold in $\mathrm{Fe}^{2+}$ loaded cells indicates that the effect is mediated, at least in part, by $\mathrm{OH}^{\bullet}$ produced from $\mathrm{H}_{2} \mathrm{O}_{2}$ by the Fenton reaction. Our data fit well with the observations that cardiac reperfusion after a brief experimental ischemia generates reactive oxygen species (O'Neill et al., 1996) and activates $\mathrm{H}_{2} \mathrm{O}_{2}$-sensitive sensory nerves. This activation is inhibited by deferoxamine pretreatment consistent with an effect mediated by $\mathrm{OH}^{\bullet}$ radicals (Ustinova and Schultz, 1994a; Huang et al., 1995b).

TRPA1 was activated by several naturally occurring alkenyl aldehydes produced by lipid peroxidation (4-HNE, 4-ONE, and 4 -HHE). The concentrations of 4 -HNE $\left(\mathrm{EC}_{50}, 19.9 \mu \mathrm{M}\right)$ and 4 -ONE $\left(\mathrm{EC}_{50}, 1.9 \mu \mathrm{M}\right)$ required to activate TRPA1 are within the concentration range of $10 \mu \mathrm{M}$ to $>100 \mu \mathrm{M}$ attained during oxidative stress (Esterbauer et al., 1991; Sayre et al., 2006). These electrophilic chemicals form adducts with many cellular molecules and the presence of these adducts is often used as an index of oxidative stress and damage. The finding that 4-HNE evokes pain responses by activating TRPA1 in vivo (Trevisani et al., 2007) supports a role for alkenyl aldehydes in signaling potentially damaging conditions of oxidative stress.

Cyclopentenone prostaglandins of the A and J series are produced in vivo by dehydration of the pentane ring of the prostaglandins, $\mathrm{PGE}_{2}$ and $\mathrm{PGD}_{2}$. The parent prostaglandins are usually produced enzymatically by the cyclooxygenase pathway. In conditions of oxidative stress, the cis-isomers of $\mathrm{PGE}_{2}$ and $\mathrm{PGD}_{2}$ (iso- $\mathrm{PGE}_{2}$ and iso- $\mathrm{PGD}_{2}$ ) are also generated nonenzymatically in vivo at high concentrations as products of free radical-induced peroxidation of arachidonoyl lipids (Chen et al., 1999; Gao et al., 2003). These isoprostanes are unstable and undergo epimerization to form $\mathrm{PGE}_{2}$ and $\mathrm{PGD}_{2}$, which in turn leads to an increased production of $\mathrm{PGA}_{2}$ and $\mathrm{PGJ}_{2}$ and their dehydration products,

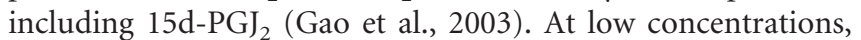
$15 \mathrm{~d}-\mathrm{PGJ}_{2}$ can exert an anti-inflammatory effect and protect against oxidative stress by activation of PPAR $\gamma$ and KEAP1 (Landar et al., 2006; Lin et al., 2006; Ou et al., 2006; Napimoga et al., 2008), but at higher concentrations, the reactive cyclopentenone prostaglandins can cause tissue damage (Koh et al., 2005; Musiek et al., 2007). Low micromolar concentrations of $15 \mathrm{~d}-\mathrm{PGJ}_{2}$ activated TRPA1. The estimated $\mathrm{EC}_{50}$ value for TRPA1 agonism (5.6 $\mu \mathrm{M})$ compares well with the concentrations of $15 \mathrm{~d}-\mathrm{PGJ}_{2}$ usually used to activate PPAR $\gamma$ (Forman et al., 1995; Kliewer et al., 1995).

Our studies show that TRPA1 can be activated by several different agents produced during conditions of oxidative stress. We propose that these chemicals activate TRPA1 and stimulate sensory neurons to elicit pain and to promote immediate protective responses either by local release of neuropeptides from the peripheral sensory nerve terminals or by sympathetically and vagally mediated neuronal reflexes. For example, activation of cardiac afferents evokes the symptoms of angina pectoris and reflex changes in blood pressure and heart rate (see e.g., Huang et al., 1995a). Similarly ROS activation of afferents innervating the airways causes a reflex increase in respiratory rate and bronchial vasodilation that increases airway blood flow (Soukhova et al., 1999; Ruan et al., 2006).

\section{References}

Andersson DA, Nash M, Bevan S (2007) Modulation of the cold-activated channel TRPM8 by lysophospholipids and polyunsaturated fatty acids. J Neurosci 27:3347-3355.

Bandell M, Story GM, Hwang SW, Viswanath V, Eid SR, Petrus MJ, Earley TJ, Patapoutian A (2004) Noxious cold ion channel TRPA1 is activated by pungent compounds and bradykinin. Neuron 41:849-857.

Bautista DM, Movahed P, Hinman A, Axelsson HE, Sterner O, Hogestatt ED, Julius D, Jordt SE, Zygmunt PM (2005) Pungent products from garlic activate the sensory ion channel TRPA1. Proc Natl Acad Sci USA 102:12248-12252.

Bautista DM, Jordt SE, Nikai T, Tsuruda PR, Read AJ, Poblete J, Yamoah EN, Basbaum AI, Julius D (2006) TRPA1 mediates the inflammatory actions of environmental irritants and proalgesic agents. Cell 124:1269-1282.

Bedard K, Krause KH (2007) The NOX family of ROS-generating NADPH oxidases: physiology and pathophysiology. Physiol Rev 87:245-313.

Bevan S, Winter J (1995) Nerve growth factor (NGF) differentially regulates 
Table 1. Comparison of $\left[\mathrm{Ca}^{2+}\right]$ responses in DRG neurons from trpa $1^{+/+}$and trpa $1^{-/-}$mice

\begin{tabular}{|c|c|c|c|c|}
\hline \multirow[b]{2}{*}{ Agonist } & \multicolumn{2}{|l|}{$\operatorname{trpa1}^{+/+}$} & \multicolumn{2}{|l|}{$\operatorname{trpa1}^{-/-}$} \\
\hline & $\begin{array}{l}\text { Responding } \\
\text { neurons }^{a}\end{array}$ & $\begin{array}{l}\text { Response amplitude } \\
\left(\% \text { of } \mathrm{K}^{+}\right)^{b}\end{array}$ & $\begin{array}{l}\text { Responding } \\
\text { neurons }^{a}\end{array}$ & $\begin{array}{l}\text { Response amplitude } \\
\left(\% \text { of } \mathrm{K}^{+}\right)^{b}\end{array}$ \\
\hline AITC & $\begin{array}{l}29 \% \\
(133 \text { of } 466)\end{array}$ & $86 \%$ & $\begin{array}{l}2 \% \\
(4 \text { of } 181)\end{array}$ & $21 \%$ \\
\hline $\mathrm{H}_{2} \mathrm{O}_{2}$ & $\begin{array}{l}33 \% \\
(91 \text { of } 274)\end{array}$ & $70 \%$ & $\begin{array}{l}3 \% \\
(12 \text { of } 403)\end{array}$ & $31 \%$ \\
\hline 4-ONE & $\begin{array}{l}31 \% \\
(97 \text { of } 310)\end{array}$ & $89 \%$ & $\begin{array}{l}7 \% \\
(27 \text { of } 364)\end{array}$ & $34 \%$ \\
\hline 4-HNE & $\begin{array}{l}28 \% \\
(98 \text { of } 356)\end{array}$ & $61 \%$ & $\begin{array}{l}1 \% \\
(4 \text { of } 469)\end{array}$ & $34 \%$ \\
\hline $15 d-P G J_{2}$ & $\begin{array}{l}32 \% \\
\text { (96 of 304) }\end{array}$ & $63 \%$ & $\begin{array}{l}10 \% \\
(15 \text { of } 148)\end{array}$ & $47 \%$ \\
\hline
\end{tabular}

${ }^{a}$ Neurons responding with a $\left[\mathrm{Ca}^{2+}\right]_{\mathrm{i}}$ increase of at least $15 \%$ of the response to a subsequent challenge with $50 \mathrm{~mm} \mathrm{KCl}$.

${ }^{b}\left[\mathrm{Ca}^{2+}\right]_{\mathrm{i}}$ increase expressed as percentage of the response to a challenge with $50 \mathrm{~mm} \mathrm{KCl}$. The weak residual $\left[\mathrm{Ca}^{2+}\right]_{\mathrm{i}}$ responses in DRG neurons from trpa $1^{-{ }^{\prime-}}$ mice were qualitatively different from the responses seen in neurons from wild-type mice and showed delayed, oscillating signals. Similar weak responses in trpa ${ }^{-/-}$DRG neurons were noted for AITC in our study and by Kwan et al. (2006). These evoked changes in $\left[\mathrm{Ca}^{2+}\right]_{\mathrm{i}}$ probably represent actions of the reactive compounds on other cellular mechanisms.

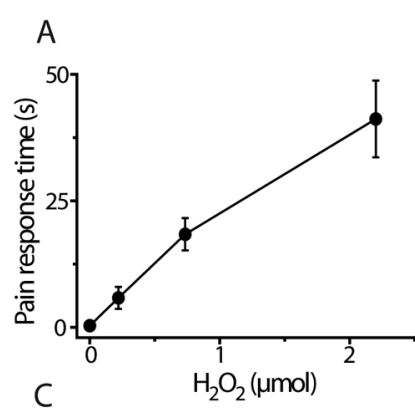

\section{B}
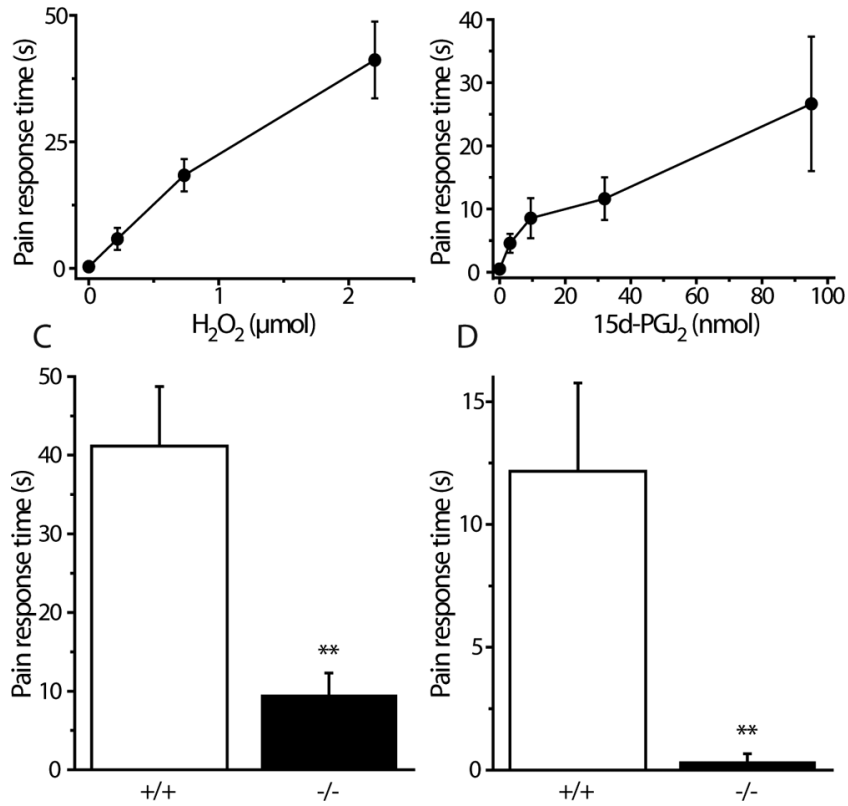

Figure 8. $\mathrm{H}_{2} \mathrm{O}_{2}$ and $15 \mathrm{~d}-\mathrm{PGJ}$ induce pain-related behavior in vivo by activating TRPA1. $A, B$, Duration of nocifensive (licking/flinching) behavior in wild-type mice evoked by intraplantar hindpaw injections of $\mathrm{H}_{2} \mathrm{O}_{2}$ in saline $(\boldsymbol{A})$ or $15 \mathrm{~d}-\mathrm{PG} \mathrm{J}_{2}$ in saline containing $10 \%$ DMSO $(\boldsymbol{B})$. The injection volume was $25 \mu$ l. Pain-related behavior was recorded over 5 min (mean $\pm \mathrm{SEM}, n=$ 6 for each group). $\boldsymbol{C}, \boldsymbol{D}$, Wild-type $(+/+)$ and TRPA1-deficient mice $(-/-)$ were injected in the hind paw with $\mathrm{H}_{2} \mathrm{O}_{2}(\mathrm{C})(2.2 \mu \mathrm{mol} / 25 \mu \mathrm{l})$ or $15 \mathrm{~d}-\mathrm{PGJ} \mathrm{J}_{2}(\boldsymbol{D})(32 \mathrm{nmol} / 25 \mu \mathrm{l})$. Pain-related behavior (licking, biting, flinching, or shaking of the injected paw) was recorded for 3 min after injection. The nocifensive responses induced by $\mathrm{H}_{2} \mathrm{O}_{2}$ and $15 \mathrm{~d}-\mathrm{PGJ}_{2}$ were dramatically reduced or absent in mice lacking TRPA1 (mean \pm SEM; $n=6$ in each group; ${ }^{* *} p<0.01$ ).

the chemosensitivity of adult rat cultured sensory neurons. J Neurosci 15:4918-4926.

Chen Y, Morrow JD, Roberts II LJ (1999) Formation of reactive cyclopentenone compounds in vivo as products of the isoprostane pathway. J Biol Chem 274:10863-10868.

Doerner JF, Gisselmann G, Hatt H, Wetzel CH (2007) Transient receptor potential channel A1 is directly gated by calcium ions. J Biol Chem 282:13180-13189.

Esterbauer H, Schaur RJ, Zollner H (1991) Chemistry and biochemistry of 4-hydroxynonenal, malonaldehyde and related aldehydes. Free Radic Biol Med 11:81-128.

Forman BM, Tontonoz P, Chen J, Brun RP, Spiegelman BM, Evans RM
(1995) 15-Deoxy-delta 12, 14-prostaglandin $\mathrm{J} 2$ is a ligand for the adipocyte determination factor PPAR gamma. Cell 83:803-812.

Gao L, Zackert WE, Hasford JJ, Danekis ME, Milne GL, Remmert C, Reese J, Yin H, Tai HH, Dey SK, Porter NA, Morrow JD (2003) Formation of prostaglandins E2 and D2 via the isoprostane pathway: a mechanism for the generation of bioactive prostaglandins independent of cyclooxygenase. J Biol Chem 278:28479-28489.

Hinman A, Chuang HH, Bautista DM, Julius D (2006) TRP channel activation by reversible covalent modification. Proc Natl Acad Sci USA 103:19564-19568.

Huang HS, Stahl GL, Longhurst JC (1995a) Cardiac-cardiovascular reflexes induced by hydrogen peroxide in cats. Am J Physiol 268:H2114-H2124.

Huang HS, Pan HL, Stahl GL, Longhurst JC (1995b) Ischemia- and reperfusion-sensitive cardiac sympathetic afferents: influence of $\mathrm{H} 2 \mathrm{O} 2$ and hydroxyl radicals. Am J Physiol 269:H888-H901.

Hyslop PA, Zhang Z, Pearson DV, Phebus LA (1995) Measurement of striatal $\mathrm{H} 2 \mathrm{O} 2$ by microdialysis following global forebrain ischemia and reperfusion in the rat: correlation with the cytotoxic potential of $\mathrm{H} 2 \mathrm{O} 2$ in vitro. Brain Res 671:181-186.

Jordt SE, Bautista DM, Chuang HH, McKemy DD, Zygmunt PM, Hogestatt ED, Meng ID, Julius D (2004) Mustard oils and cannabinoids excite sensory nerve fibres through the TRP channel ANKTM1. Nature 427:260-265.

Kim D, Cavanaugh EJ (2007) Requirement of a soluble intracellular factor for activation of transient receptor potential Al by pungent chemicals: role of inorganic polyphosphates. J Neurosci 27:6500-6509.

Kliewer SA, Lenhard JM, Willson TM, Patel I, Morris DC, Lehmann JM (1995) A prostaglandin J2 metabolite binds peroxisome proliferatoractivated receptor gamma and promotes adipocyte differentiation. Cell 83:813-819.

Koh SH, Jung B, Song CW, Kim Y, Kim YS, Kim SH (2005) 15-Deoxydelta12,14-prostaglandin J2, a neuroprotectant or a neurotoxicant? Toxicology 216:232-243.

Kondo M, Oya-Ito T, Kumagai T, Osawa T, Uchida K (2001) Cyclopentenone prostaglandins as potential inducers of intracellular oxidative stress. J Biol Chem 276:12076-12083.

Kwan KY, Allchorne AJ, Vollrath MA, Christensen AP, Zhang DS, Woolf CJ, Corey DP (2006) TRPA1 contributes to cold, mechanical, and chemical nociception but is not essential for hair-cell transduction. Neuron 50:277-289.

Lambeth JD (2004) NOX enzymes and the biology of reactive oxygen. Nat Rev Immunol 4:181-189.

Landar A, Zmijewski JW, Dickinson DA, Le Goffe C, Johnson MS, Milne GL, Zanoni G, Vidari G, Morrow JD, Darley-Usmar VM (2006) Interaction of electrophilic lipid oxidation products with mitochondria in endothelial cells and formation of reactive oxygen species. Am J Physiol Heart Circ Physiol 290:H1777-H1787.

Levonen AL, Landar A, Ramachandran A, Ceaser EK, Dickinson DA, Zanoni G, Morrow JD, Darley-Usmar VM (2004) Cellular mechanisms of redox cell signalling: role of cysteine modification in controlling antioxidant defenses in response to electrophilic lipid oxidation products. Biochem J 378:373-382.

Lin D, Lee HG, Liu Q, Perry G, Smith MA, Sayre LM (2005) 4-Oxo-2nonenal is both more neurotoxic and more protein reactive than 4-hydroxy-2-nonenal. Chem Res Toxicol 18:1219-1231.

Lin TN, Cheung WM, Wu JS, Chen JJ, Lin H, Chen JJ, Liou JY, Shyue SK, Wu KK (2006) 15d-prostaglandin J2 protects brain from ischemiareperfusion injury. Arterioscler Thromb Vasc Biol 26:481-487.

Macpherson LJ, Dubin AE, Evans MJ, Marr F, Schultz PG, Cravatt BF, Patapoutian A (2007a) Noxious compounds activate TRPA1 ion channels through covalent modification of cysteines. Nature 445:541-545.

Macpherson LJ, Xiao B, Kwan KY, Petrus MJ, Dubin AE, Hwang S, Cravatt B, 
Corey DP, Patapoutian A (2007b) An ion channel essential for sensing chemical damage. J Neurosci 27:11412-11415.

Musiek ES, McLaughlin B, Morrow JD (2007) Electrophilic cyclopentenone isoprostanes in neurodegeneration. J Mol Neurosci 33:80-86.

Nagata K, Duggan A, Kumar G, Garcia-Anoveros J (2005) Nociceptor and hair cell transducer properties of TRPA1, a channel for pain and hearing. J Neurosci 25:4052-4061.

Napimoga MH, Souza GR, Cunha TM, Ferrari LF, Clemente-Napimoga JT, Parada CA, Verri Jr WA, Cunha FQ, Ferreira SH (2008) 15dprostaglandin $\mathrm{J} 2$ inhibits inflammatory hypernociception: involvement of peripheral opioid receptor. J Pharmacol Exp Ther 324:313-321.

Nilius B, Talavera K, Owsianik G, Prenen J, Droogmans G, Voets T (2005) Gating of TRP channels: a voltage connection? J Physiol (Lond) 567:35-44.

O’Neill CA, Fu LW, Halliwell B, Longhurst JC (1996) Hydroxyl radical production during myocardial ischemia and reperfusion in cats. Am J Physiol 271:H660-H667.

Ou Z, Zhao X, Labiche LA, Strong R, Grotta JC, Herrmann O, Aronowski J (2006) Neuronal expression of peroxisome proliferator-activated receptor-gamma (PPARgamma) and 15d-prostaglandin J2-mediated protection of brain after experimental cerebral ischemia in rat. Brain Res 1096:196-203.

Petersen DR, Doorn JA (2004) Reactions of 4-hydroxynonenal with proteins and cellular targets. Free Radic Biol Med 37:937-945.

Poole LB, Karplus PA, Claiborne A (2004) Protein sulfenic acids in redox signaling. Annu Rev Pharmacol Toxicol 44:325-347.

Ruan T, Lin YS, Lin KS, Kou YR (2005) Sensory transduction of pulmonary reactive oxygen species by capsaicin-sensitive vagal lung afferent fibres in rats. J Physiol (Lond) 565:563-578.

Ruan T, Lin YS, Lin KS, Kou YR (2006) Mediator mechanisms involved in TRPV1 and P2X receptor-mediated, ROS-evoked bradypneic reflex in anesthetized rats. J Appl Physiol 101:644-654.

Sayre LM, Lin D, Yuan Q, Zhu X, Tang X (2006) Protein adducts generated from products of lipid oxidation: focus on HNE and one. Drug Metab Rev 38:651-675.

Schultz HD, Ustinova EE (1998) Capsaicin receptors mediate free radical- induced activation of cardiac afferent endings. Cardiovasc Res 38:348-355.

Shibata T, Yamada T, Ishii T, Kumazawa S, Nakamura H, Masutani H, Yodoi J, Uchida K (2003) Thioredoxin as a molecular target of cyclopentenone prostaglandins. J Biol Chem 278:26046-26054.

Soukhova GK, Ahmed M, Fletcher EC, Yu J (1999) Hydrogen peroxide in the lung parenchyma stimulates vagally mediated phrenic activity. Chest 116:1365-1368.

Sprong RC, Aarsman CJ, van Oirschot JF, van Asbeck BS (1997) Dimethylthiourea protects rats against gram-negative sepsis and decreases tumor necrosis factor and nuclear factor $\kappa \mathrm{B}$ activity. J Lab Clin Med 129:470-481.

Stahl GL, Pan HL, Longhurst JC (1993) Activation of ischemia- and reperfusion-sensitive abdominal visceral C fiber afferents. Role of hydrogen peroxide and hydroxyl radicals. Circ Res 72:1266-1275.

Stone JR, Yang S (2006) Hydrogen peroxide: a signaling messenger. Antioxid Redox Signal 8:243-270.

Trevisani M, Siemens J, Materazzi S, Bautista DM, Nassini R, Campi B, Imamachi N, Andre E, Patacchini R, Cottrell GS, Gatti R, Basbaum AI, Bunnett NW, Julius D, Geppetti P (2007) 4-Hydroxynonenal, an endogenous aldehyde, causes pain and neurogenic inflammation through activation of the irritant receptor TRPA1. Proc Natl Acad Sci USA 104:13519-13524.

Uchida K (2003) 4-Hydroxy-2-nonenal: a product and mediator of oxidative stress. Prog Lipid Res 42:318-343.

Ustinova EE, Schultz HD (1994a) Activation of cardiac vagal afferents in ischemia and reperfusion. Prostaglandins versus oxygen-derived free radicals. Circ Res 74:904-911.

Ustinova EE, Schultz HD (1994b) Activation of cardiac vagal afferents by oxygen-derived free radicals in rats. Circ Res 74:895-903.

Voets T, Droogmans G, Wissenbach U, Janssens A, Flockerzi V, Nilius B (2004) The principle of temperature-dependent gating in cold- and heatsensitive TRP channels. Nature 430:748-754.

Yoshida T, Inoue R, Morii T, Takahashi N, Yamamoto S, Hara Y, Tominaga M, Shimizu S, Sato Y, Mori Y (2006) Nitric oxide activates TRP channels by cysteine S-nitrosylation. Nat Chem Biol 2:596-607. 